\title{
Determination of Acrylamide Contents in Grilled Meat and Fish Foods through Gas Chromatography Tandem Mass Spectrometry (GC-MS/MS) in Bangladesh
}

\author{
G. M. M. ANWARUL HASAN ${ }^{1 *}$, MOHAMMED A. SATTER ${ }^{1}$, \\ MD. MAHBUBUL MORSHED ${ }^{2}$ and ANUJ KUMER DAS ${ }^{3}$ \\ ${ }^{1}$ Institute of Food Science and Technology (IFST), Bangladesh Council of Scientific and \\ Industrial Research (BCSIR), Dr. Qudrat-E-Khuda Road, Dhaka 1205, Bangladesh. \\ ${ }^{2}$ Department of Biochemistry and Molecular Biology, Jahangirnagar University, Savar, \\ Dhaka-1342, Bangladesh. \\ ${ }^{3} \mathrm{Hi}-\mathrm{Tech}$ Health care Ltd, Pharmaceutical products wholesaler in Dhaka, Bangladesh. \\ ${ }^{*}$ Corresponding author E-mail: pd-cbirmdp@bcsir.gov.bd \\ http://dx.doi.org/10.13005/ojc/370505
}

(Received: September 06, 2021; Accepted: October 18, 2021)

\section{ABSTRACT}

Grilled foods are important source of acrylamide which has neurotoxic, genotoxic and carcinogenic properties. In the present study, 105 grilled meat and fish foods were analyzed through Gas Chromatography Tandem mass spectrometry (GC-MS/MS) to detect acrylamide concentrations in Bangladesh. The average acrylamide contents in grilled chicken, tandoori chicken, chicken tikka kabab, chicken fry, beef kabab, beef grill, grilled fish were $80.27 \mu \mathrm{g} / \mathrm{Kg}, 99.34 \mu \mathrm{g} / \mathrm{Kg}, 83.13$ $\mu \mathrm{g} / \mathrm{Kg}, 73.98 \mu \mathrm{g} / \mathrm{Kg}, 68.19 \mu \mathrm{g} / \mathrm{Kg}, 81.52 \mu \mathrm{g} / \mathrm{Kg}$ and $48.39 \mu \mathrm{g} / \mathrm{Kg}$ respectively. The differences in the acrylamide contents in the products of same category were because of differences in thermal treatments during the preparation. In comparison with other studies, the results suggested that, consumption of those foods is safe for the consumers. This study will focus light on the fate of acrylamide during food processing and provide valuable information to access potential health risks through consumption of those foods.

Keywords: Acrylamide, GC-MS/MS, Grilled meat, Grilled fish, Bangladesh.

\section{INTRODUCTION}

People change their food habits due to changes in their lifestyles, economies and global culture. In $20^{\text {th }}$ century, fried food items are very popular among all types of people, especially in young generation ${ }^{1}$. Frying is one of the most popular methods of food preparation now-a-days.
Fried foods are popular because of their attractive flavor, color and crisp texture. To produce healthy food items several parameters such as minerals, carbohydrates, lipids, proteins, vitamins, enzymes, and other nutrients should be properly maintained. But due to heat, light, oxygen, solvent $\mathrm{pH}$ sensitivity or the combined effect of these parameters food nutrients can be damaged during food processing ${ }^{2}$.

This is an Open Access article licensed under a Creative Commons license: Attribution 4.0 International (CC- BY). Published by Oriental Scientific Publishing Company @ 2018 
The nutritional value of food is deteriorated and decreased because of frying of those foods as during frying oils exposed high heat. Now-a-days, another recent concern added with fried food including Acrylamide, a naturally occurring chemical which produces during high temperature cooking and then converted to glycidamide, which is a possible mutagen and reproductive toxicant ${ }^{3}$.

Acrylamide (AA) is a colorless, odorless and water soluble crystalline solid. It is commonly used to make multi-purpose polymers and in molecular biology research ${ }^{4,5}$. It is produced in wide range of foods such as French fries, potato chips, cereal, bread and coffee during frying, roasting and baking ${ }^{6}$. The synthesis of acrylamide linked to Maillard processes (a process where reaction occurs between asparagine and reducing sugars), which produce molecules responsible for food's smashing taste, fragrance, and color ${ }^{7}$. This chemical is now well known as one of the thermal degradation products of triacylglycerol which occurs during hightemperature food processing. Acrylamide contents in foods depend on the starting concentrations of asparagine and reducing sugars. Other factors such as temperature, duration of heat treatment, water activity and $\mathrm{pH}$ also have effect on acrylamide formation in food $^{8,9,10}$. Since the Swedish National Food Administration announced that acrylamide had been discovered in heat-treated foods ${ }^{11}$, it has become a major human health concern, and various researches have been published on the compound's toxicity, production, and detection ${ }^{12,13,14,15}$.

A large amount of acrylamide was discovered in several foods processed at high temperatures in $2002^{11}$. Acrylamide levels were found to be moderate $(5-50 \mathrm{lg} / \mathrm{kg})$ in heated protein-rich diets and higher $(150-4000 \mathrm{lg} / \mathrm{kg})$ in carbohydrate-rich diets ${ }^{6}$. The detection of extremely high amounts of acrylamide (more than $10 \mathrm{mg} / \mathrm{kg}$ ) in overcooked fried chips indicated that cooking temperature and duration have an impact on acrylamide production. According to World Health Organization (WHO), daily consumable acrylamide intake of adults about 0.3 to $2.0 \mathrm{lg} / \mathrm{kg} / \mathrm{body}$ wt. and in case of children the intake rate is higher because of the body weight ratio differences ${ }^{16}$.

Based on its carcinogenic effect in rats, the International Agency for Research on Cancer categorized the industrial chemical acrylamide as a potential human carcinogen in 1994. It's a well-known neurotoxic. Although, the World Health Organization has set a restriction of 0.5 $\mathrm{mg} / \mathrm{kg}$ for acrylamide in drinking water while no restriction in food have been determined ${ }^{17}$. The Joint Expert Committee of the FAOMHO on Food Additives (JECFA) released a statement stating that the toxicological concern posed by acrylamide consumption with food cannot be ruled out ${ }^{18}$. For this reason, research is going on for lowering acrylamide concentrations in food $18,19,20,21$.

The most often used methods for quantifying acrylamide are GC-MS or LC-MS/MS, which are followed by multi-step sample preparation processes $^{22}$. Both LC-MS/MS and GC-MS/MS are reliable methods for acrylamide detection because of high accuracy, sensitivity, stability and reproducibility. Although, the both of the methods are very costly but, still HPLC-MS/MS and GC- MS/MS are reliable methods for acrylamide detection.

The objective of this study was to determine the acrylamide concentrations in grilled meat and fish foods by GC-MS/MS.

\section{MATERIALS AND METHODS}

\section{Chemicals and standards}

Acrylamide (99\% pure), isotope labeled internal standard (IS) d3, analytical grade Methanol (99\% pure), Acetonitrile (99\% pure), Magnesium Sulphate (99\% pure), sodium hyposulphite (99\% pure) and n-Hexane (99\% pure) were bought from Merck (Darmstadt, Germany).

\section{Collection of sample}

For sampling, meat and fish foods that required high temperature for processing were considered. Foods of those categories including grilled chicken, tandoori chicken, chicken tikka kabab, chicken fry, beef kabab, beef grill, grilled fish were collected from the local restaurants of Dhaka, Bangladesh. A total of 105 samples (15 samples of each category) were collected. A small portion of Sample after homogenizing was stored at $4^{\circ} \mathrm{C}$ in vacuum and light proof container until further analysis. During the sample processing at least three replicates of each sample were properly stored and analyzed. The whole procedure including sample processing and analysis was carried out between February, 2021 and June, 2021. 


\section{Extraction}

Samples were homogenized first with a grinder and $1.50 \mathrm{~g}$ of samples was transferred to a $50 \mathrm{~mL}$ centrifuge tube. $500 \mu \mathrm{l}$ of internal standard solution (acrylamide-d3) was added with the homogenized samples and kept for $10 \mathrm{~min}$ to mix properly. Then, extraction was done with water at $60^{\circ} \mathrm{C}$ in ultrasonic bath (Model: XUB10; Grant Instruments, UK). The mixed sample was centrifuged at $12,000 \mathrm{rpm}$ for $15 \mathrm{~min}$ and shaked with $\mathrm{n}$-hexane for defatting process. The water phase was collected and brominated $(\mathrm{KBr}, \mathrm{HBr}+\mathrm{KBrO} 3)$ for overnight and sodium hyposulphite was used to remove excess bromine from the solution. Later extraction was done two times with ethyl acetate. Finally, extracted organic layer was evaporated to dryness and dissolved with ethyl acetate ${ }^{23}$ prior injection.

\section{GC-MS analysis}

GC-MS was used for both method validation and quantification of acrylamide in grilled meat and fish food items of Dhaka, Bangladesh. $2 \mu \mathrm{l}$ of extracted samples were injected on GC-MS system. Acrylamide concentrations were detected a through Gas Chromatography system (TRACE 1310, Thermo Fisher Scientific, USA) with Trace GOLD ${ }^{\mathrm{TM}}$ TG-WAX GC Column $(0.25 \mathrm{~mm} \times 0.25 \mu \mathrm{m} \times 0.30 \mathrm{~m})$ column. The carrier gas was Helium at a flow rate of $1 \mathrm{ml} /$ minute. Injection port temperature was $240^{\circ} \mathrm{C}$ while $50^{\circ} \mathrm{C}$ to $260^{\circ} \mathrm{C}$ was the temperature range during GC. Ion traps used in this analysis was $\mathrm{m} / \mathrm{z}$ 152; product ion was $\mathrm{m} / \mathrm{z} 135$ and m/z 155; product ion $\mathrm{m} / \mathrm{z} 137$ for acrylamide di bromo and derivatives and $\mathrm{d} 3$ labelled acrylamide dibromo derivative internal standard respectively. Collision energy was $1 \mathrm{~V}$ and ion source temperature was $230^{\circ} \mathrm{C}$. Acrylamide contents in the analyzed samples were detected by calculating ion peaks m/z 135 and m/z 137 ratio areas. AMass spectrometry (TSQ DUO, Thermos Scientific, USA) was applied for spectral data collection. Results were calculated based on the mean value of three replicates of each sample.

\section{Standard curve, limit of detection (LOD) and Limit of quantification (LOQ)}

Five different concentrations of standard solutions from $5 \mathrm{ppb}$ to $200 \mathrm{ppb}$ were injected into the column for determination of the linearity of standard curve. LOD and LOQ values were achieved through average blank value method. The signal to noise ratio (3:1) was considered for LOD determination of acrylamide while 10 times of baseline noise value was considered to compute $L O Q$ value.

\section{Evaluation of Recovery performance}

The method was evaluated through recovery rate study. Fresh samples were adulterate with two different concentrations such as $5 \mu \mathrm{g} / \mathrm{kg}$ and $10 \mu \mathrm{g} / \mathrm{kg}$. Then, acrylamide was extracted from those spiked samples in a same procedure of extraction from the analyzed samples. This recovery evaluation was repeated at least three times and percentage mean value with standard deviation (SD) was considered for evaluation of recovery performance.

\section{Data analysis}

The results were arranged through Microsoft Office Excel 2007 and Statistics 10 software was used for statistics and calculation.

\section{RESULTS AND DISCUSSION}

\section{Method validation}

A linear standard calibration curve with R2 value of 0.999 was observed in standard solutions. A chromatogram showing a peak representing acrylamide in standard solution is depicted in Fig. 1. The LOD values obtained 10.67, 9.61, 11.92, $9.17,7.49,11.23$ and 10.68 for grilled chicken, tandoori chicken, chicken tikka kabab, chicken fry, beef kabab, beef grill, grilled fish respectively. The LOQ values were 29.67, 30.29, 33.67, 29.76, 31.63, 27.57 and 33.82 for grilled chicken, tandoori chicken, chicken tikka kabab, chicken fry, beef kabab, beef grill, grilled fish respectively (Table 1 ).

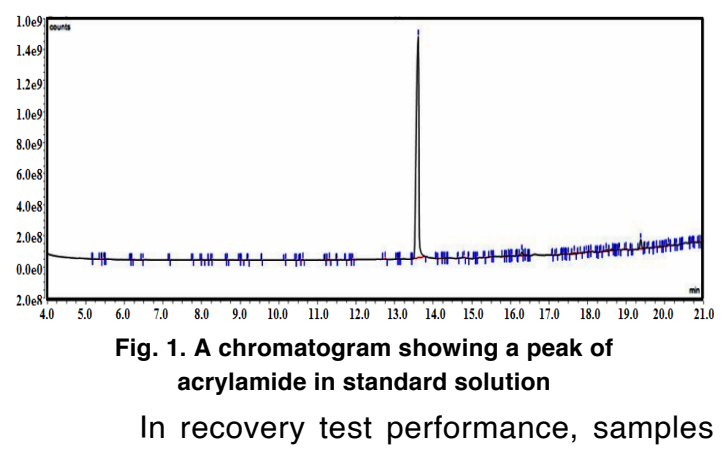
were spiked with acrylamide standard. The percent recoveries $(5 \mu \mathrm{g} / \mathrm{Kg}$ spiked) obtained in this study were $73.34 \pm 4.76,77.29 \pm 3.98,87.34 \pm 5.90,92.20$ $\pm 4.93,74.56 \pm 3.39,93.80 \pm 5.48,94.91 \pm 5.66$, $88.32 \pm 3.39$ and $82.15 \pm 5.19$ for grilled chicken, tandoori chicken, chicken tikka kabab, chicken fry, 
beef kabab, beef grill, grilled fish respectively while The percent recoveries $(10 \mu \mathrm{g} / \mathrm{Kg}$ spiked) were 86.48 $\pm 4.69,80.93 \pm 5.40,81.44 \pm 5.23,87.40 \pm 5.37,81.56$ $\pm 5.44,86.77 \pm 3.32,96.18 \pm 6.93,76.45 \pm 5.42$ and $80.58 \pm 4.39$ for grilled chicken, tandoori chicken, chicken tikka kabab, chicken fry, beef kabab, beef grill, grilled fish respectively (Table 2 ).

\section{Acrylamide concentrations in grilled meat and fish foods}

In this study, acrylamide contents were detected in the range from 40.39-112.32 $\mu \mathrm{g} /$
Kg (mean: $80.27 \mu \mathrm{g} / \mathrm{Kg}$ ), 54.12-152.53 $\mu \mathrm{g} /$ Kg (mean: $99.34 \mu \mathrm{g} / \mathrm{Kg}$ ), 39.21-129.06 $\mu \mathrm{g} / \mathrm{Kg}$ (mean: $83.13 \mu \mathrm{g} / \mathrm{Kg}$ ), 49.37-110.54 $\mu \mathrm{g} / \mathrm{Kg}$ (mean: $73.98 \mu \mathrm{g} / \mathrm{Kg}$ ), <LOQ-104.38 $\mu \mathrm{g} / \mathrm{Kg}$ (mean: 68.19 $\mu \mathrm{g} / \mathrm{Kg}$ ), 32.18-148.69 $\mu \mathrm{g} / \mathrm{Kg}$ (mean: 81.52 $\mu \mathrm{g} / \mathrm{Kg}$ ), <LOQ-67.81 $\mu \mathrm{g} / \mathrm{Kg}$ (mean: $48.39 \mu \mathrm{g} / \mathrm{Kg}$ ) for grilled chicken, tandoori chicken, chicken tikka kabab, chicken fry, beef kabab, beef grill, grilled fish respectively (Table 1 ). Among the analyzed samples, acrylamide contents were detected below the limit of detection in $25 \%$ of beef kabab and $35 \%$ of fish grill samples.

Table 1: Detected acrylamide concentrations $(\mu \mathrm{g} / \mathrm{Kg}), \mathrm{SD}$, LOD and LOQ values of analyzed samples

\begin{tabular}{|c|c|c|c|c|c|c|}
\hline Items & Number of Samples & Mean $(\mu \mathrm{g} / \mathrm{Kg})$ & SD & Range & LOD $(\mu \mathrm{g} / \mathrm{kg})$ & LOQ $(\mu \mathrm{g} / \mathrm{kg})$ \\
\hline Grilled chicken & 15 & 80.27 & 21.24 & $40.39-112.32$ & 10.67 & 29.67 \\
\hline Tandoori chicken & 15 & 99.34 & 17.42 & $54.12-152.53$ & 9.61 & 30.29 \\
\hline Chicken tikka kabab & 15 & 83.13 & 29.21 & $39.21-129.06$ & 11.92 & 33.67 \\
\hline Chicken fry & 15 & 73.98 & 32.48 & $49.37-110.54$ & 9.17 & 29.76 \\
\hline Beef kabab & 15 & 68.19 & 26.32 & $<L O Q-104.38$ & 7.49 & 31.63 \\
\hline Beef grill & 15 & 81.52 & 23.92 & $32.18-148.69$ & 11.23 & 27.57 \\
\hline Grilled fish & 15 & 48.39 & 17.65 & $<$ LOQ-67.81 & 10.68 & 33.82 \\
\hline
\end{tabular}

SD: Standard Deviation

Table 2: Obtained results from recovery test

\begin{tabular}{lcc}
\hline Samples & $\begin{array}{c}\text { \% recovery } \\
(5 \mu \mathrm{g} / \mathrm{Kg})\end{array}$ & $\begin{array}{c}\% \text { recovery } \\
(10 \mu \mathrm{g} / \mathrm{Kg})\end{array}$ \\
\hline Grilled chicken & $77.23 \pm 3.67$ & $76.18 \pm 4.32$ \\
Tandoori chicken & $81.15 \pm 4.83$ & $75.43 \pm 3.53$ \\
Chicken tikka kabab & $77.40 \pm 6.32$ & $84.18 \pm 4.38$ \\
Chicken fry & $83.42 \pm 5.91$ & $89.47 \pm 3.43$ \\
Beef kabab & $89.16 \pm 5.19$ & $74.66 \pm 4.47$ \\
Beef grill & $87.11 \pm 3.77$ & $76.33 \pm 5.39$ \\
Grilled fish & $90.81 \pm 4.56$ & $88.23 \pm 4.98$ \\
\hline
\end{tabular}

From this analysis, highest level of acrylamide was detected in tandoori chicken which are followed by beef grill, chicken tikka kabab, chicken fry, grilled chicken, beef kabab and grilled fish samples. Variable acrylamide concentrations in samples of same category may be dependent on raw materials, different processing methods, heating time and cooking type during the preparation. Variable acrylamide contents were detected may be because of the processing style in different restaurants. Zhang et al., ${ }^{24}$ reported acrylamide concentration of $164-225 \mu \mathrm{g} / \mathrm{Kg}$ in fried chicken wings and in minced beef and chicken, acrylamide concentration was detected as $17 \mu \mathrm{g} / \mathrm{Kg}$ and $28 \mu \mathrm{g} / \mathrm{kg}$ respectively ${ }^{25}$. By comparing with similar other studies, this study concluded that, grilled meat and fish foods contained low concentration of acrylamide which is not much harmful for health. No potential health risks are associated with the consumption of grilled meat and fish foods in Bangladesh.

\section{CONCLUSION}

This study reports the acrylamide contents in grilled chicken, tandoori chicken, chicken tikka kabab, chicken fry, beef kabab, beef grill, grilled fish collected from Dhaka, Bangladesh. The analyzed results indicated that, acrylamide was present in almost in every sample and the ranges from below the $\angle \mathrm{LOQ}$ to $152.53 \mu \mathrm{g} / \mathrm{kg}$ and high level of standard deviation among the samples were observed. Therefore, it is necessary to access health risks due to consumption of acrylamide through consumption of those commonly consumed grilled meat and fish foods.

\section{ACKNOWLEDGEMENT}

The study was supported by funding from ADP project allocated by Ministry of Science of Technology (MOST), Bangladesh Government.

\section{Conflict of interests}

The authors declare no conflict of interest. 


\section{REFERENCES}

1. Khan, M.; Moniruzzaman, M.; Razu, M.H. Nutr. Food Sci., 2019, 10(7), 876-92.

2. Karmas, E., and Harris, R.S. Nutritional Evaluation of Food Processing, Springer, Dordrecht., 2014.

3. Barber, D.S.; Hunt, J.R.; Ehrich, M.F.; Lehning, E.J.; LoPachin, R.M. Neurotoxicology., 2001, 22(3), 341-53.

4. Erkekoğlu, P.; Baydar, T. Nutr. Res. Rev., 2010, 23(2), 323-33.

5. Riboldi, B.P.; Vinhas, Á.M.; Moreira, J. D. Food Chem., 2014, 157, 310-22.

6. Ahn, J.S.; Castle, L.; Clarke, D.B.; Lloyd, A.S.; Philo, M.R.; Speck, D.R. Food Addit Contam., 2002, 19(12), 1116-24.

7. Zhang, Y.; Ren, Y.; Zhang, Y. Chem. Rev., 2009, 109(9), 4375-97.

8. Claus, A.; Carle, R.; Schieber, A. J. Cereal Sci., 2008, 47(2), 118-33.

9. Hedegaard, R.V.; Santos, C.; Yin, T.Y.; Skibsted, L.H. Aust. J. Chem., 2014, 67(5), 805-12.

10. Moon, J.K.; Shibamoto, T. J. Agric. Food Chem., 2009, 57(5), 1655-66.

11. Tareke, E.; Rydberg, P.; Karlsson, P.; Eriksson, S.; Törnqvist, M. J. Agric. Food Chem., 2002, 50(17), 4998-5006.

12. Skog, K.; and Alexander, J. Wood head publishing., 2006.

13. Dybing, E.; Farmer, P.B.; Andersen, M.; Fennell, T.R.; Lalljie, S.P.; Müller, D.J.; Olin, S.; Petersen, B.J.; Schlatter, J.; Scholz, G.; Scimeca, J. A. Food Chem. Toxicol., 2005, 43(3), 365-410.
14. Zhang, Y.; Zhang, G.; Zhang, Y. J. Chromatogr. A., 2005, 1075(1-2), 1-21.

15. Wenzl, T.; De, La.; Calle, M.B.; Anklam, E. Food Addit Contam., 2003, 20(10), 885-902.

16. Becalski, A.; Lau, B.P.; Lewis, D.; Seaman, S.W. J. Agric. Food Chem., 2003, 51(3), 802- 8.

17. Galdo, V.C.; Massart, C.; Jin, L.; Vanvooren, V.; Caillet-Fauquet, P.; Andry, G.; Lothaire, P.; Dequanter, D.; Friedman, M.; Van Sande, J. Mol. Cell. Endocrinol., 2006, 257, 6-14.

18. Joint FAO/WHO Experts Committee on Food Additives (JECFA). Summary and conclusions of the sixty-fourth meeting of the Joint FAOMHO Experts Committee on Food Additives (JECFA), Rome, 8-17 February, 2005, JECFA/64/SC.

19. Alves, R.C.; Soares, C.; Casal, S.; Fernandes, J.O.; Oliveira, M.B. Food Chem., 2010, 119(3), 929-34.

20. EC (European Commission). Monitoring of acrylamide levels in food 2007, 2007/331/EC.

21. EC (European Commission). Monitoring of acrylamide levels in food., 2010, 2010/307/EU.

22. Pedreschi, F.; Segtnan, V.H.; Knutsen, S.H. Food Chem., 2010, 121(2), 616-20.

23. Castle, L. J. Agric. Food Chem., 1993, 41, 1261-1263.

24. Zhang, Y.; Dong, Y.; Ren, Y.; Zhang, Y. J. Chromatogr. A., 2006, 1116(1-2), 209-16.

25. Petersson, E.V.; Rosén, J.; Turner, C.; Danielsson, R.; Hellenäs, K.E. Anal. Chim. Acta., 2006, 557(1-2), 287-95. 